\title{
Boil the Plan, But Do Not Fry The Issue; Indonesian Cooking Terms Metaphor in Media
}

\author{
Muhammad Adam ${ }^{1}$, Rosmiati $^{2}$ \\ ${ }^{1,2}$ Universitas Balikpapan \\ e-mail: $\underline{1}$ adam@uniba-bpn.ac.id ${ }^{2}$ rosmiati@uniba-bpn.ac.id

\begin{tabular}{ccc}
\hline Diterima & Direvisi & Disetujui \\
$22-06-2020$ & $11-08-2020$ & $13-08-2020$ \\
\hline
\end{tabular}

\begin{abstract}
Abstrak - Cultural aspect and experiential basis is two of the components in the metaphor production. Several studies have been conducted in conceptual metaphor framework, but there haven't many of the studies relate how the daily Indonesian cultural life affects the metaphor production. This paper aims to focus on the use of Indonesian cooking terms in media news headlines. The conceptual metaphor theory (Lakoff and Johnson, 1980) is used as the theoretical framework. Qualitative method is used during this study with purposive sampling data collection method. The source of the data is ten news headlines from Indonesian online media news that use cooking terms metaphor. The result shows that the metaphorical use of Indonesian cooking terms come from two types, the first is the level of cooking with words mentah (raw/undercooked), and matang (fully cooked) to describe a progress of a plan or policy draft, and the second type is process of cooking by using godok (to boil) and goreng (to fry) but with a different target domain. The result also shows that the use of godog (to boil) as metaphor refer to a plan or a program that are being prepared and being discussed and implies a positive association, whereas the metaphorical use of menggoreng (to fry) tends to be more negative as it refers to an exaggerated political issue
\end{abstract}

Key words : Conceptual Metaphor, Cooking terms metaphor, cultural context

\begin{abstract}
Abstrak - Aspek budaya dan basis eksperiental merupakan dua diantara beberapa komponen dalam sebuah metafora. Beberapa kajian telah dilakukan dalam kerangka teori metafora konseptual, namun belum banyak kajian yang menghubungkan aspek keseharian budaya Indonesia yang mempengaruhi metafora yang digunakan. Studi ini mengkaji tentang penggunaan istilah memasak dalam judul berita media online berbahasa Indonesia. Kerangka teori yang digunakan dalam studi ini adalah Teori Metafora Konseptual. Metode yang digunakan dalam studi ini adalah metode kualitatif dengan menggunakan sepuluh judul berita yang menggunakan istilah memasak sebagai sumber data. Hasil studi menunjukkan bahwa penggunaan istilah memasak terbagi menjadi dua jenis, yang pertama adalah level kematangan seperti mentah dan matang yang mendeskripsikan tahap perkembangan sebuah rencana atau penyusunan aturan, dan yang kedua adalah proses memasak, yang menggunakan godok dan goreng dangan ranah target yang berbeda. Hasil kajian juga memperlihatkan bahwa penggunaan kata godok memiliki asosiasi yang cenderung positif, sedangkan goreng lebih berasosiasi negatif karena merujuk pada rumor (politik) yang dibesar-besarkan.
\end{abstract}

Kata Kunci: Metafora Konseptual, Metafora istilah memasak, konteks budaya.

\section{INTRODUCTION}

The study of cooking terms metaphor has attracted attention many metaphor scholars (Negro, 2019; Tsaknaki, 2016; Vasudevan, 2015), nevertheless, the study of cooking metaphor in Indonesian context related to the cultural social life of Indonesian speakers embedded in metaphorical expressions receives less attention or even as far as our knowledge has never become a focus of any previous studies. This paper aims to fill the gaps by investigating those aspects in the use of cooking terms metaphor in Indonesian headline news and relate that with the embedded cultural and social life behind the metaphor.
The social and cultural life are two of the component that develop human conceptual and cognitive domain, as asserted by Rahman (2019) that humans also interact with each other within a complex social environment and develop values and norms to regulate such interactions. Through these interactions, humans produce culture in various forms such as language, technology, traditions, social norms and so forth and one of the manifestation of how the interaction of the experience and culture is embedded in language is the use of metaphor.

Metaphor simply speaks about one thing that is abstract by using terms from another thing which is more descriptive and easy to understand. The function of metaphor itself is not only on decorative 
function of metaphor in literature as Muller (2008) described that metaphor has been primarily regarded as a matter of language that serves a multitude of functions, with the most pertinent ones operating in language change and in poetic language.

The use of metaphor in media is widely acknowledged as an important tool as it provides a vivid and clearer description to what idea to be shared. Therefore, the uses of metaphor as a tool in headlines are frequently used. One of the metaphors that are widely used in Indonesian context is the cooking terms metaphor.

In Indonesian spoken context, food and cooking metaphor is frequently use. Some examples are : Kritik pedas (a hot critics) that uses to describe a critics, minta mentah nya saja (just give the raw/the cash) which sometimes uttered if someone wants a cash instead of goods or souvenir as a tip.

This study takes data from online media news headlines that use the metaphor of Indonesian cooking terms, particularly godok (to boil), goreng (to fry), mentah (under cooked) and matang (well done/fully cooked). Headlines are a particularly powerful way in which key messages are conveyed to the reader, including those who do not go on to read the article in full or in depth. The use of metaphorical expressions in news headlines will contribute to an extra power of news headlines (Munro, 2018). Whereas Thi \& Hang (2016) affirms that as one of the common rhetorical devices, metaphor is splashed across the front pages of newspapers that bring certain image effects to the readers' minds at the same time. Furthermore, Kovecses (2018) affirms that context-induced metaphor use in headlines is a common phenomenon as they headlines provide a clear pragmatic functions, drawing the readers' attention, being sensational, etc. In Indonesian context, various studies on metaphor in headlines have been conducted; in economic discourse for instance, Adam (2020) reports how the Indonesian health insurance BPJS Kesehatan- is described as the sick patient to refer to its financial conditions.

This research uses the Conceptual Metaphor Theory (CMT) of Lakoff and Johnson as the framework as it provides the tool to be able to analyse the aspects that involve in the source domain and target domain of metaphor. CMT theory rejects the traditional view of metaphor that views metaphor only as literary device. Instead, Lakoff and Johnson (1980) asserts that we are not speaking metaphorically, but we tend to think metaphorically and adds that our ordinary conceptual system, in terms of which we both think and act, is fundamentally metaphorical in nature. Thus, the metaphorical expression is basically the explicit realization of an implicit conceptual way of thinking.
An example of how we think metaphorically and then is realized with metaphorical expressions is by thinking that LOVE is A JOURNEY. By conceptually think that way, it then trigger the metaphorical expressions:

\section{Our relationship will not going anywhere}

\section{We hit a dead-end}

\section{Our marriage is in the cross road.}

In metaphorical expressions above, the love is expressed as it is a journey. In CMT, the conceptual level mapping is written in capital letters. There are two domains in conceptual metaphor, the source domain and the target domain. In the example above, The target domain is LOVE and the source domain is JOURNEY.

In this study the source domain is COOKING terms, and will focus on what metaphorical expressions from cooking terms that is used to speak about other domain to be able to identify the target domain.

Kovecses (2003) affirms that metaphor is seen as a composition of ten components that interact, namely: (1). Experiential basis, which motivates the choice of particular sources to map into particular targets (2). Source domain (3). Target domain (4). Relationship between the source and the target is that a source domain can apply to several targets and a target can attach to several sources (5).Metaphorical linguistic expressions are the result of the particular pairings of those domains (6).There are basic conceptual correspondences, or mappings, between the source and target domains, source domains often map materials onto the target beyond the basic correspondences and these additional mappings and may result (7). Entailments or inferences and (8). Blends. (9). Conceptual metaphors often materialize in nonlinguistic ways, that is, not only in language and thought but in social reality (10). Conceptual metaphors converge on, and often produce, cultural models, that is, holistically structured conceptual units.

The conceptual metaphor mapping and its metaphorical expression is not always universal, the cultural context is very important in shaping the mapping of both domains in particular language. Littlemore \& Low, (2006) provides a view of the sources of cross-cultural variation of metaphor, the first is history and behavior, the second is social organization and the third is physical environment, whereas Kovecses (2010) claims that there are two main causes of cross - cultural variations. They are broader cultural context and the natural and physical environment in which different cultures are located. 
The study of how cultural context trigger a metaphorical expressions is conducted by one of them Almirabi (2015) and finds that metaphor similarities or differences between languages could be a result of differences in one or more of the metaphor shaping factors which are: extent of different cultures, geographic environments, speaker's values and personality, thinking modes, mental concepts, views of the world, feelings, and human relationships

This paper aims to have a deep look into the use of Indonesian cooking terms as metaphorical expressions in media news headlines which receive less attention. Throughout this study, the term metaphor and metaphorical expressions is used interchangeably.

\section{RESEARCH METHODOLOGY}

Qualitative method is used during this study and the source of the data is ten news headlines from Indonesian online media news that use cooking terms metaphor that are purposively chosen. Headlines news are used as the data as it provides the metaphorical expressions needed and available to be taken efficiently.

To be able to identify metaphor in discourse, Metaphor Identification Procedures (MIP) is used Praglejaz Group is used (Group, 2007). Thus, this study focuses on specific source domain of cooking terms, therefore, the identification of cooking terms in headline is conducted during data collection, then the next stage with using MIP is to identify if the cooking terms word is used metaphorically.

Each metaphorical expression of cooking terms that is found is classified based on the type of cooking condition and cooking process, from the first stage mentah (raw/undercooked) to matang (fully cooked), then cooking process godok (to boil) and goreng (to fry).

In data analysis stage, authors use interpretative method to identify the surrounding context of each metaphor use and to be able to interpret the properties transferred from the source domain (COOKING terms) to the target domain. During this stage, the implied characteristics of the cooking terms will be mapped onto the target domain.

\section{FINDING AND DISCUSSION}

The finding is presented based on two classifications, which is the level of cooking terms, from raw to fully-cooked and the cooking process, which is to boil and to fry. The conceptual interpretation of the level of cooking can be universally understood as it does not vary significantly among cultures, whereas the different use of cooking process as metaphorical expressions in Indonesian language is affected by its cultural background as presented below :

\section{The Metaphorical expression of Cooking Terms in news headlines}

Cooking terms as metaphor used in media headlines comes from two types, the first on use the level of cooking and the second one using the cooking process.

\section{A. Level of Cooking}

There are two main cooking terms metaphor related to the level of cook and are presented below:

\section{1). Mentah (undercooked)}

The use of mentah (undercook) in metaphorical expression below is used to describe the proposal to expand the Papua province. The conceptual implication of the word undercook itself suggests something that is unfinished and the process is still on progress.

Headline 1

Mahfud MD: Rencana Pemekaran Provinsi di Papua Belum Matang, Masih Mentah. (Yahya, 2019)

(Mahfud MD : The plan for Papua Province division is not fully-cooked, still undercook)

There are two metaphorical expressions used in data 1 above, the first is belum matang (not fully cooked) and the second one is masih mentah (still undercooked). Both metaphorical expressions implies similar entailments and is used as an adjective to describe the proposal or the plan, which means that it still require a further and comprehensive studies before reaching any decision. In the case of data 1 above, the plan is related to the division of Papua onto few more provinces. The analogy of undercooked entails that there is a need for more times and more works to do before taking a conclusion.

The use of under-cooked is also found in the headline 2 below, but with a different Indonesian lexeme which is masih mentah (still raw and synonymous with undercooked).

Headline 2 
Plafon Anggaran Defisit Rp 10 T, Sekda DKI Sebut Masih Mentah. (Wijaya, 2019)

(The budget's limit deficit Rp 10 Trillion, Jakarta Province Secretary says it still raw)

By mentioning that the budget plan is still raw, it entails that this number is not the final one, instead, similar to data above, the entailments appear from the use of "still undercooked" metaphorical expressions implied that there is still the need to do more consideration and calculation before reaching the final amount.

\section{2). Matang (Fully cooked)}

The next level of cooking terms that is used as metaphorical expressions is the word matang (fully cooked or well-done cooked) as seen in headlines below

Headline 3 below provides a headline about the plan to invite foreign rector to Indonesia and will be expected to be able to boost the quality of the universities. The discussion surrounding the idea attract many educational experts to speak whether against or support the plan. One of the comments regarding the plan comes from Indonesian Lecturers Association and suggests that the government should examine carefully the plan before executing it, and the metaphorical expressions is used for that:

Headline 3:

Asosiasi Dosen Indonesia: Kaji Matang Rencana 'Impor' Rektor (Sinintya, 2019)

(Indonesian Lecturers Association : Cook well the plan to import rector)

Conceptually, when someone is asked to cook the food until it is fully cooked, it means that the process has been done thoroughly. This concept then is used as the analogical properties that are mapped onto another domain to describe vividly that something must be carefully examined and be considered before doing it.

In headline 3 above, the plan to invite foreign rectors is viewed as a premature discussion, and there is the need to consider various aspects before executing the plan.

The same properties also seen in headline 4 below, where the East Java province government is considering the plan to build hanging train in Bromo. This plan is still at the preliminary stage, and the headline describes the plan as the process to go to the fully cooked level.

Headline 4
Pemprov Jatim Matangkan Rencana Bangun Kereta Gantung di Gunung Bromo （Hartik, 2019)

(East Jave Province Government fully cook the plan to build hanging train in Mount Bromo)

The cooking level word is used as a verb is matangkan (to cook until it is fully cooked) means that the plan to build the hanging train is still an undergoing discussion, and the East Java Government has the intention to implement the idea. The process of planning until the idea is complete and ready to be implemented is conceptually described as the cooking process.

Whereas in headline 5 below, the discussion is about the government plan to move the capital city to East Kalimantan. This is a huge plan, and there must be many aspects to take as considerations. The headline 5 below express how government should pay attention to those many aspects by using metaphorical expression of perencanaan matang (fully cooked plan)

\section{Headline 5}

Pemerintah Diminta Siapkan Perencanaan Matang atas Pemindahan Ibu Kota (Paksha, 2019)

(Government is asked to prepare fully cooked plan regarding city capital relocation)

Different from headline 3 and headline 4 above, where the metaphorical expressions use as a verb, in headline 5, the word matang (fully cooked) is used as an adjective and modifies the noun plan.

\section{B. Process of Cooking}

Headlines below use the process of cooking as the metaphorical expressions.

\section{1). Godok (To boil)}

Godok (to boil) is a javanese word, and the Indonesian translation is rebus (to boil). The interesting aspect is when expressing to boil something literally, both words can be used, but when used metaphorically, rebus (to boil) is hardly found, whereas godok with spelling variation godog (to boil) is commonly used.

Headline 6

Tarif Tiket Pesawat Mahal, Kemenhub Godok Aturan Baru (JPNN, 2019)

(The plane ticket fare is expensive, Transportation Ministry boil new regulation) 
In headline 6 above, the topic is about how the ministry of transportation plan to issue a new policy regarding the high price of plane ticket. The process of preparing this new policy is described metaphorically using the word godok (to boil).

In headline 7 below, the news describe the plan to expand construction project by one of Indonesian State Own enterprise in construction, Waskita Karya.

The plan to expand the construction project to Mecca is expressed using the same metaphorical expression of cooking process, godok (to boil).

\section{Headline 7}

Waskita Karya Godok Rencana Pembangunan di Mekkah (Priambodo, 2019)

\section{(Waskita Karya boils the plan for construction} In Mecca)

From two headlines above that use cooking process of godok (to boil) as metaphorical expression in describing a process of planning something entails that this process should be carefully done and should be done in a correct and timely manner. The experiential basis of boiling a food particularly in traditional Indonesian society particularly in Javanese traditional way of boiling (from which the word godok originally from) requires a full attention and takes a longer process compare to other cooking process. Thus, this conceptual culturally view is embedded in the use of metaphorical expressions.

\section{2). Goreng (to fry)}

One other cooking terms used as metaphorical expression from cooking process is to fry with different target domain from the previous metaphorical expressions. The metaphorical use of (meng)goreng (to fry) is used to describe a political issue and it entails a different connotation as it mainly used to describe an action when someone is exaggerating a fact or a news.

As seen in headline 8 below, the headline is about the news surrounding a video from one of Indonesian famous singer, Agnez Monica. In the video that is broadcasted in you tube, Agnez talks from which country or race she is originally from, and she mentioned that she has the Germany, China and Japanese descent. This triggers some misinterpretation and sparks debate about the video. During the situation, the Indonesian Palace that represents the office of Presidency asks people not to exaggerate the issue.

\section{Headline 8:}

Istana: Soal Agnez Mo Jangan Digoreng-goreng (Online, 2019)

(Indonesian Palace : about Agnez Mo, It shouldn't be fried)

The metaphorical expression in headline 8 above, originally quoted from the palace representation, and since it meets the headlines style of language which one of them contains metaphor, the quote is directly used in the news headline. Asking the issue not to be fried literally means to ask people stop exaggerating the issue.

Whereas in headline 9 below, the headline presents how Hendropriyono, one of Indonesian retired general and now a politician expresses his opinion and disappointment on how Australian media reports the situation in Papua, one of provinces in Indonesia.

\section{Headline 9}

Hendropriyono Kesal Media Australia Terus Menggoreng Isu Papua (JPNN.com, 2019)

(Hendropriyono is upset that Australian media keeps frying the Papua issue)

By using metaphorical expression "frying the Papua issue" it means that the issue about Papua has been exaggerated. The negative connotation is implied from the use of this metaphorical expression, which is also similar in headline 10 below.

\section{Headline 10}

Timses Jokowi Bantah Ikut Goreng Isu Prabowo Jumatan Dimana (Nurita, 2019)

(Jokowi campaign team denies frying the issue "where Prabowo takes Friday pray)

The issue discussed in headline 10 is emerged from the speculation when people wante to know where one of the presidential candidates Prabowo takes Friday pray. Since this issue emerged before the Indonesian presidential election, with a heated political atmosphere, the political coalition that support candidacy ask people not to exaggerate the issue about where Prabowo takes the Friday pray. There was an accusation to the rival's campaign team of exaggerating the issue, but it was then denied.

In headlines 10 above, by expressing that the issue of where Prabowo takes Friday pray means that there is a tendency to exaggerate and to always talk about this issue.

From headline 8 , headline 9 and headline 10 above, the use of (meng)goreng (to fry) is always associated with a political issue. When it is fried, it means the 
issue is exaggerated and might be spread out of its proportion, thus, this particular cooking term metaphorical expression tends to have a negative connotation.

Another observation also raised by Hastuti DP (personal communication, August 11, 2020), who discusses that in another context, the metaphorical use of men(goreng) (to fry) also means to broach a particular subject, that it always becomes a hot subject to discuss. Conceptually, a hot fried snack and a hot issue have the conceptual similarity in terms of its interest for people. Also, additional observation by Hastuti DP on the conceptual elements of this word that enable it to be used metaphorically is the experiential basis of frying activity, that trigger a noisy sound caused by water from the food to be fried is exposed to the vegetable oil. This cause a noisy sound, therefore, this experiential basis is understood as the people noisy sound when discussing a hot issue.

C. The Metaphorical Mapping and The Cultural aspect in Indonesian cooking terms metaphor.

The cooking terms used as metaphorical expressions seen above is possible because there are properties from the source domain COOKING terms that can be transferred to target domain A PLAN. The metaphorical mapping and the entailments are as below:

Table 1. Source Domain-Target Domain Mapping - Target Domain : A Plan / A Policy

\begin{tabular}{|l|l|}
\hline $\begin{array}{l}\text { SOURCE DOMAIN : } \\
\text { COOKING }\end{array}$ & $\begin{array}{l}\text { TARGET DOMAIN: } \\
\text { A PLAN / A POLICY }\end{array}$ \\
\hline Level of Cooking & $\begin{array}{l}\text { The Progress of a plan } \\
\text { or policy draft }\end{array}$ \\
$\begin{array}{l}\text { Mentah } \\
\text { Undercooked }\end{array}$ & $\begin{array}{l}\text { Still in Progress / Poorly } \\
\text { Planned }\end{array}$ \\
$\begin{array}{l}\text { Matang (Well done/fully } \\
\text { cooked) }\end{array}$ & $\begin{array}{l}\text { Plan completed / Policy } \\
\text { completed }\end{array}$ \\
$\begin{array}{l}\text { Process of cooking } \\
\text { Godok (to boil) (V) }\end{array}$ & $\begin{array}{l}\text { To carefully plan / to } \\
\text { prepare a policy }\end{array}$ \\
\hline
\end{tabular}

From the mapping above, entailments followed are when a plan is at an early stage, it is still raw, the higher the cooking level, the better the progress of a plan, and the completed plan is described as a fully cooked plan.

Whereas in particular to word goreng (to fry), the target domain is different.

Table 2 : Table 1. Source Domain-Target Domain Mapping - Target Domain : A political issue

\begin{tabular}{|l|l|}
\hline SOURCE DOMAIN & $\begin{array}{l}\text { TARGET DOMAIN: } \\
\text { A POLITICAL ISSUE }\end{array}$ \\
\hline $\begin{array}{l}\text { Process of cooking } \\
\text { Goreng (to fry) }(\mathrm{V})\end{array}$ & to exaggerate the issue. \\
\hline
\end{tabular}

It entails that when an issue is fried; it is exaggerated and is diverted from the fact. The act of frying an issue then brings a negative connotation when it used metaphorically. There is a deterioration of meaning from its conceptual meaning. Also, as noted by Hastuti DP (Personal communication, August 11, 2020), another experiential basis from the frying activity is the noise the comes from the frying process that is mapped as the people discussion regarding a particular issue.

The aspect of culture in metaphor is highlighted by many scholars two of them is by Gannon (2004) that provides a description of how cultural metaphors provide a window into other cultures and suggests that cultural metaphors can accelerate general understanding or sensitivity. Furthermore, Kovecses (2005) agrees that the following items influence the differentiation of metaphors: Context (Physical environment geography, flora and fauna, dwellings, etc), Social (power relations, social pressure and cultural and further added other influence which is Experiential Focus (references to personal body).

In the case of the use of cooking level terms as metaphorical expressions, there is a combination of cultural context and experiential focus, as it suggest the same conceptual universal properties, that when the cooking process is not fully done, it means that the food is still raw or under cook and is not consumable. This conceptual properties enable the cooking level to be transferred to speak about other domain and might logically interpreted. Nevertheless, in English language, the cooking level terms is not commonly used to metaphorically describe a plan or a level or progress, whereas in Indonesia the use of cooking level terms of mentah (raw), belum matang (undercooked), and matang (fully cooked) is frequent.

Using the cooking level terms to speak about the progress of a plan or a development will be easily understood by hearer or reader when it is used to explain a $\mathrm{n}$ abstract concept. Cooking level terms provide a more descriptive and vivid image of the level of progress.

The second cooking terms used as metaphorical expression is the cooking process. The cooking process in Indonesia has affected the way speakers use and perceive the word. Godok (to boil) is a process where it must be carried out carefully 
and must not be completed before the boiling process is done. To boil a food entails that the process is still undergo. What interesting in the use of this word godok is that the word is originally from Javanese, and is used in Indonesian formal metaphor.

The Indonesian equal word, rebus (to boil) for Indonesian speakers must not share same cultural and experiential basis with how Javanese speakers perceived godok (to boil), thus, the word rebus (to boil) is not used metaphorically to refer to the process of planning something.

This differences may lies on the cultural differences of traditional boiling process in Javanese culture where the process might be done longer, carefully watched. Whereas the word rebus might already too close to the modern Indonesian urban people and use the more modern boiling method with an automatic timer which in turn does not require more attention and efforts.

The second cooking term word that related to Indonesian cultural and embodied experience background is menggoreng (to fry). In Indonesian ways, frying is not done with a deep fry method, but using enough vegetable oil and require the cooker to flip the fried food a few times upside down. This is then is implied as not leaving something as the way it is, and will bring a significant change on the original forms of the fried item before and after the frying process. Even it may cause an imperfection to the items fried. This component is then transferred to the analogy used to talk about a story or a rumour, which may cause a story change or diversion from what originally is.

Other aspect to highlight from the use of cooking process terms, is that using godok (to boil) brings a positive connotation as it entails that the subject is carefully planning something, whereas using goreng (to fry) as metaphorical expression suggest a negative connotation, as it means that the subject is doing something improper. There might be also unintended entailments that may emerge from the use of metaphorical expressions.

\section{CONCLUSION}

Having analyzed the metaphorical expressions from cooking terms metaphor in ten headlines, researchers conclude that the use of cooking terms extend from the word mentah (raw/undercooked) to matang (fully cooked) when speaking about the level of progress of a plan or a draft of a policy, whereas when metaphorically speaking about the process of preparing a plan or a policy draft, godok (to boil) is used.
Other cooking process word used metaphorically is goreng (to fry) to refer to an exaggerated political issue. Thus, for the metaphorical use of the word goreng (to fry), the target domain is different from the others.

The result also shows that the use of godok (to boil) as metaphor refer to a plan or a program that are being prepared and being discussed and implies a positive association, whereas the metaphorical use of menggoreng (to fry) tends to be more negative as it refers to a political rumor.

The cultural and experiential aspect of Indonesian life reflects from the use of the word godok (to boil) and goreng (to fry), which metaphorically used in two different concept. The last aspect is the certain metaphorical expression carries a connotation as seen on how godok (to boil) connotatively different with the metaphorical use of the word goreng (to fry).

This study in a small extend shall provide a view on how the social cultural life of Indonesian speaker is embedded in the metaphor production especially in cooking terms metaphor.

Further study should be conducted to further examine how the word rebus (to boil) of Indonesian word is not used as metaphor as godok (to boil) by relating it to the etymological origin of those words.

\section{REFERENCES}

Adam, M. (2020). Metaphor of BPJS Kesehatan as a Sick Patient in Indonesian Media Headlines. ELS Journal on Interdisciplinary Studies in Humanities, 3(1), 10-21.

Almirabi, M. (2015). When Metaphors Cross Cultures. Journal of Language Teaching and Research, 6(1), 204-209.

Gannon, M. J. (2004). Understanding Global Cultures: Me ltures: Metaphorical taphorical Journeys Through 28 Nations Clusters of Nations Nations Clusters of Nations and Continents and Continents (3rd ed.). CA: Thousand Oaks.

Group, P. (2007). MIP : A Method for Identifying Metaphorically Used Words in Discourse. Metaphor \& Symbol, 22(1), 1-39.

Hartik, A. (2019, July 28). Pemprov Jatim Matangkan Rencana Bangun Kereta Gantung di Gunung Bromo. Kompas.Com. Retrieved from https://regional.kompas.com/read/2019/07/28/1 5133391/pemprov-jatim-matangkan-rencana- 
bangun-kereta-gantung-di-gunung-bromo

JPNN.com. (2019, December 23). Hendropriyono Kesal Media Australia Terus Menggoreng Isu Papua. JPNN.Com. Retrieved from https://www.jpnn.com/news/hendropriyonokesal-media-australia-terus-menggoreng-isupapua

JPNN. (2019). Tarif Tiket Pesawat Mahal, Kemenhub Godok Aturan Baru. JPNN. Com. Retrieved from https://www.jpnn.com/news/tarif-tiketpesawat-mahal-kemenhub-godok-aturan-baru

Kovecses, Z. (2003). Language, Figurative Thought, and Cross-Cultural Comparison. Metaphor \& Symbol, 18(4), 311-320.

Kovecses, Z. (2005). Metaphor in Culture. Universality and Variation. New York/Cambridge: Cambridge University Press.

Kovecses, Z. (2010). Metaphor - A Practical Introduction. London: Oxford University Press.

Kovecses, Z. (2018). METAPHOR IN MEDIA LANGUAGE AND COGNITION : III(1). https://doi.org/10.2478/lart-2018-0004

Lakoff, George and Johnson, M. (1980). Metaphor We Live By. Chicago: University of Chicago Press.

Littlemore, J., \& Low, G. (2006). Figurative thinking and foreign language learning. Figurative Thinking and Foreign Language Learning, 1239. https://doi.org/10.1057/9780230627567

Muller, C. (2008). Metaphors Dead and Alive, Sleeping and Walking - A Dinamic View. Chicago: University of Chicago Press.

Munro, M. (2018). Munro, M. ( 2018$)$ House price inflation in the news: a critical discourse analysis of newspaper coverage in the UK. Housing Studies , 33 ( 7 ). 33(January), 10851105. https://doi.org/10.1080/02673037.2017.142191 1

Negro, I. (2019). Metaphor and Metonymy in Food Idioms. Languages, 4(3). https://doi.org/doi:10.3390/languages4030047

Nurita, D. (2019, February 14). Timses Jokowi Bantah Ikut Goreng Isu Prabowo Jumatan Dimana. Tempo.Co. Retrieved from https://pilpres.tempo.co/read/1175767/timsesjokowi-bantah-ikut-goreng-isu-prabowojumatan-dimana
Online, W. (2019, November 27). Istana: Soal Agnez Mo Jangan Digoreng-goreng. Warta Ekonomi.Co.Id. Retrieved from https://www.wartaekonomi.co.id/read258589/is tana-soal-agnez-mo-jangan-digorenggoreng.html

Paksha, E. (2019, August 7). Pemerintah Diminta Siapkan Perencanaan Matang Pemindahan Ibu Kota. TigaPilarNews.Com. Retrieved from https://www.tigapilarnews.com/berita/2019/08/ 07/127281-Pemerintah-Diminta-SiapkanPerencanaan-Matang-Pemindahan-Ibu-Kota

Priambodo, Y. (2019, July 26). Waskita Karya Godok Rencana Pembangunan di Mekkah. Kompas.Tv. Retrieved from https://www.kompas.tv/article/51208/waskitakarya-godok-rencana-pembangunan-di-mekkah

Rahman, F. (2019). Save the world versus man-made disaster: A cultural perspective. https://doi.org/10.1088/17551315/235/1/012071

Sinintya, W. (2019, August 7). Asosiasi Dosen Indonesia: Kaji Matang Rencana "Impor" Rektor. CNBC Indonesia. Retrieved from https://www.cnbcindonesia.com/news/2019080 7161451-4-90490/asosiasi-dosen-indonesiakaji-matang-rencana-impor-rektor

Thi, N., \& Hang, T. (2016). Sport Metaphors in Political News Headlines. 32(2), 12-20.

Tsaknaki, O. (2016). Cooking verbs and metaphor Contrastive study of Greek and French. (2004), 458-472.

Vasudevan, S. (2015). Cooking As Metaphor Of The Solitary Voice Of Women With Respect To Laura Esquivel 's Like Water For Chocolate. 4(7), 44-47.

Wijaya, L. D. (2019, November). Plafon Anggaran Defisit Rp 10 T, Sekda DKI Sebut Masih Mentah. Tempo. Co. Retrieved from https://metro.tempo.co/read/1274576/plafonanggaran-defisit-rp-10-t-sekda-dki-sebutmasih-mentah

Yahya, A. N. (2019, December 17). Mahfud MD : Rencana Pemekaran Provinsi di Papua Belum Matang, Masih Mentah. Tribun Papua. Retrieved from https://papua.tribunnews.com/2019/12/17/mahf ud-md-rencana-pemekaran-provinsi-di-papuabelum-matang-masih-mentah 